\title{
Research on Problems and Countermeasures of Tourism Poverty Alleviation in China from the Perspective of Industrial Chain
}

\author{
Zhou Xiaowei, Bao Zhipeng* \\ International Business School of Shaanxi Normal University \\ Xi'an, China
}

\begin{abstract}
There are many poor aspects of China tourism poverty alleviation effect, and one of the reasons lies in the microfoundation of tourism poverty alleviation industry -- the industrial chain fails to highlight the inherent benefits of tourism poverty alleviation without realization of the effective integration of regional resources. From the perspective of industry chain, combined with the present situation and development of tourism poverty alleviation in China, through literature review and survey analysis, this paper tries to find out some problems of the current tourism poverty alleviation in China, thereby improving China's tourism poverty alleviation countermeasures. This paper aims at promoting the development of tourism poverty alleviation in China, reducing the poor population, and striving to realize the goal of building a well-off society in an all-round way at an early date.
\end{abstract}

Keywords-Tourism poverty alleviation; Industry chain; Rural tourism; Countermeasure research

\section{INTRODUCTION}

Poverty has always threatened the survival and development of human beings all over the world. The eradication of poverty and the realization of common prosperity are the Shared vision of people all over the world. China is the largest developing country in the world, with a relatively large number of poor people. In order to realize the goal of comprehensive well-off society in 2020, how to get rid of poverty is a difficult problem in China and even the world. Rural tourism resources are abundant in poor areas of China, and according to statistics, China's rural tourism resources account for $70 \%$ of the national tourism resources, and more than half of China's poor villages have the conditions to develop rural tourism [1].Tourism can promote the poverty reduction in the region has become the consensus of the domestic and foreign academic circles, according to the research, about a third of the poor people in China have benefited from the tourism poverty alleviation work in this region. Through the development of the local tourism industry, the local economy has been promoted, and the per capita income level has been raised. Finally, the population of the region has been lifted out of poverty. Tourism poverty alleviation work in China since the $1980 \mathrm{~s}$, after more than 30 years of development, tourism poverty alleviation work taking shape in our country, has obtained certain achievement [2].
According to the data released by the National Bureau of statistics in February 1, 2018, the number of rural poor in the country was 30.46 million at the end of 2017 , and the number of rural poor in China fell by 12.89 million over the previous year. In 2017, the per capita disposable income of rural residents in poor areas was 9377 yuan, an increase of 894 yuan over the previous year, the actual increase of $9.1 \%$ and the actual increase of 0.7 percentage points over the previous year, which was 1.8 percentage points higher than the national average level in the country [3]. Although tourism poverty alleviation has achieved good results, but there are many areas in China there are some problems. Yunnan, guizhou, guangxi, henan, sichuan and other provinces and autonomous regions have more than 5 million poor people. Although the overall poverty rate declined, the incidence of poverty in some provinces and autonomous regions remained above $15 \%$ [4].Moreover, the distribution of poverty-stricken areas is mostly scattered, which is a great challenge for the development and implementation of poverty alleviation work. This paper tries to analyze the causes of existing problems from the perspective of industrial chain, and provides some suggestions for the countermeasures.

\section{PROBlems Existing IN THE INDUSTRIAL CHAIN PERSPECTIVE OF TOURISM POVERTY ALLEVIATION}

\section{A. Tourism poverty alleviation industry chain is short}

Tourism emphasizes cross-industry and interregional cooperation and communication, which is a comprehensive and highly correlated industry. China's tourism industry chain is short for poverty alleviation, across industries, crossregional extension was not enough. Mainly reflected in: firstly in the cross-industry extension, tourism poverty alleviation industry and other related industries are not integrated enough. Tourism poverty alleviation industry related to tourism six elements: "food, accommodation, transportation, traveling, shopping, entertainment", and extensive contact with agriculture, industry, business [5]. As one of the most important forms of tourism in China, most of the rural tourism is still only in the utilization stage of primary agricultural products. The first, second and third industries are not integrated with each other. The tourism industry has a weak link between the industry and the industry, and it has been 
severely limited to the use of tourism to alleviate poverty. Secondly, in the trans-regional extension, tourism poverty alleviation industry has not been able to integrate the tourism resources, and the horizontal cooperation is relatively small. The complementary functions of adjacent scenic spots have not been fully developed, and most of the scenic spots are alone and the situation of resource sharing has not been realized.

\section{B. Tourism poverty alleviation core enterprise drive is insufficient}

Tourism poverty alleviation core enterprises drive and contain other tourism poverty alleviation enterprises. The formation of tourism poverty reduction industry chain should be based on the core tourism poverty alleviation enterprise [6]. However, the cooperation between China's tourism poverty alleviation enterprises is weak, and it pays too much attention to the competition with upstream and downstream enterprises of the industrial chain, hindering the development of enterprises. Most of the enterprises are small in scale, weak in strength, poor in market development, weak in brand awareness, and lack of momentum in the development of tourism poverty alleviation. For all reasons, no core enterprise is formed in most of our tour and poor areas in China. In addition, in the tourism industry structure, the four elements of "food, accommodation, transportation, traveling" are the basic elements or basic consumption of tourism, which belong to the chain with little flexibility. The expense of entertainment and shopping, it's not basic consumption, it's very resilient, and it's worth more than the first four. However, China's tourism industry chain only has a strong agglomeration effect on the basic consumption of low added value, which is weak in the development of non-basic consumption with high added value and elasticity.

\section{Tourism poverty alleviation and development is blind}

Tourism poverty alleviation is mostly in remote mountainous areas, each region has its own unique development resources and advantages. However, due to a large number of local governments eager to achieve success, and people in poor areas are eager to improve their life and poverty through development of tourism, they lack the early scientific investigation, rational argument, tourism market research and analysis, and blindly carry out tourism poverty alleviation and development. For example, many rural tourism products are designed to be single, and they are not combined with local practice and repeated imitation, resulting in low level and repeated construction of rural tourism products, lack of features and innovation, weak competitiveness and weak attraction to tourists, and poor tourism economic benefits [7]. At present, most of the rural tourism in most areas is mainly sightseeing, lack of supporting and participatory tourism projects, which can easily lead to visual fatigue and boredom, and rural tourism has not formed the core competitiveness, thus affecting the sustainable development of tourism poverty alleviation.

\section{Tourism poverty alleviation input mechanism is single}

The developments of rural tourism in mountainous areas, ecological fragility and unique geographical environment have led to great demand, heavy workload and deep difficulty in the development of tourism projects. In addition, the remote mountainous areas lack the infrastructure to develop tourism facilities, and the roads and communication equipment need to be improved in the future, which requires a large amount of capital and high development costs. Poor investment and financing environment in poverty-stricken areas and the institutional barriers of tourism management system are restricted. There are few channels for poverty alleviation and financing in poverty-stricken areas, and the investment mechanism is single. The local government is the main body of the tourism poverty alleviation and development investment. Although the government has increased the fund support for the poverty alleviation of rural tourism in recent years, because the development funds of the project mainly rely on the government input, the source is too single, and the financial input is limited, it is difficult to meet the actual development demand, and thus the effect of using rural tourism development to alleviate poverty. This leads to many parts of the rural tourism has long been at low levels and extensive primary development phase, also has restricted the development of rural tourism development and the transformation and upgrading of poor areas.

\section{E. Low participation in poverty}

In the vast rural areas of China, the poor farmers are constrained by the factors such as the quality of the people, the receiving of information, the investment and the opportunity of development, so that the concept of peasant households lags behind the development of the society, which does not treat the tourism industry as a new industry for poverty eradication. Due to the lack of relevant development funds and skills, and the weak participation awareness and participation ability of rural tourism development, the majority of poor households are excluded from the benefit groups of rural tourism development, and it is difficult to share the huge benefits brought by rural tourism development. Lack of representation and decision-making in that development and operation of tourism, and the marginalization of tourist interest, may foster dissatisfaction. In addition, in some rural areas of China, there are cases where the target of poverty alleviation is aimed away, or even the contradiction between "strengthening and unstrengthening" [8].Moreover, the development of rural tourism may interfere with the normal life of the farmers, and the influx of tourists will also cause the inconvenience of transportation, damage to the environment and price increase, and increase the living cost of poor farmers. Rural tourism has not been widely accepted and participated by poor farmers, which has restricted the development of poverty alleviation work in rural tourism. 


\section{COUNTERMEASURES AND SUGGESTIONS FOR DEVELOPING TOURISM POVERTY ALLEVIATION FROM THE PERSPECTIVE OF INDUSTRIAL CHAIN}

\section{A. To strengthen industrial chain integration}

The development of tourism poverty alleviation cannot be separated from the integration and optimization of resources. In order to achieve the development goal of tourism poverty alleviation, we need to optimize the rural industrial structure and extend the industrial chain so as to integrate the first, second and third industries and increase the employment opportunities. All regions should optimize the industry integration according to their own resource advantages, and promote the common development of tourism and agriculture, catering industry, transportation and service industry according to local conditions. The chain of tourism and poverty is an organic whole, and it has to look at the whole thing, and strengthen the integration of the tourism industry chain. And through the integration of tourism poverty alleviation industry chain, it can give play to the synergistic effect of tourism poverty alleviation industry, thus reducing the transaction cost between enterprises and reducing the pressure of tourism market. In addition, the development of tourism poverty alleviation should break the traditional boundary of tourism, expand tourism poverty alleviation industry, extend the tourism poverty alleviation industry chain, promote resource integration and industrial integration, and finally realize the extension and expansion of tourism poverty alleviation industry chain, and promote the value-added of industry and the participation of local residents in tourism.

\section{B. To accelerate the localization of the tourism chain}

The focus of tourism poverty alleviation should be the local residents in the poverty-stricken areas, and the tourism poverty alleviation and development should be the first priority for the local people. The rural tourism poverty alleviation and development of our country should make full use of the special advantages of rural tourism and strong correlation, and extend the development of hotel management, breeding industry, agricultural and sideline products processing industry and transportation industry in rural tourism poverty alleviation, and even the related industries such as the decoration industry, construction industry and cultural industry, so as to form a localized industrial chain and maximize the utilization of local labor and resources. In this way, the self-sufficiency of tourism related products can be expanded, and the local characteristics of tourism products can be added to improve the added value of local agricultural products, so that local residents are willing to participate in tourism development and obtain tangible benefits.

\section{To speed up the development of tourism poverty alleviation core enterprise}

It is imperative to cultivate a group of competitive antipoverty enterprises. The only way to increase the value of the industrial chain is to increase the value of the industry and the distribution of its value by growing the core of the tourism industry. The development of tourism industry chain should be centered on core enterprises, and other enterprises cooperate with each other to gradually form the industrial chain pattern with the regional multi-core tourism poverty alleviation enterprise as the leader. First of all, the local government should attract investment through policies, introduce those enterprises with strong strength and strong capital, and establish a tourism core enterprise with integrated operation capability, and integrate rural tourism resources, elements and upstream and downstream industry chains. It would be better to use local investors, to avoid excessive development of rural resources, and to make a profit and ignore the problem of poverty reduction. In addition, for some poor villages to open their own travel business in a variety of ways by attracting foreign investment, collective financing, and the people of the village, the local government should encourage it, and give a certain standard of guidance, and it will give the appropriate support to the policy.

\section{To build a multi-channel fund-raising system}

Due to the influence of various factors in the tourism poverty alleviation and development process, the capital investment is large, and the poor areas lack a large amount of source of funds. Although the government is the main body of tourism poverty alleviation and development, it is far from enough to rely on the government to invest funds. It is necessary to attract multiple subjects to participate in and build a multi-channel financing system. If the local government does "one size fits all" and ignores the social and market effects, the effect will be counterproductive. Therefore, it is suggested that relevant departments of the state formulate corresponding credit policies, play the role of policy-based finance, and provide special loans for the construction of rural tourism infrastructure. At the same time, the local government should actively broaden the financing channels, to attract domestic and foreign private enterprises, social organizations and individual citizens participate in rural tourism poverty alleviation, strengthen rural tourism construction funds, and clear the main body of social responsibility and the role of, let the social from all walks of life of poverty as its responsibility and mission. In addition, tourism poverty alleviation can be combined with education poverty alleviation, micro-credit poverty alleviation and other forms of poverty alleviation, so as to form synergy and promote the development of tourism poverty alleviation. 


\section{E. To enhance the poor participation}

To promote the development of rural tourism in povertystricken areas, we should constantly improve the mechanism of profit distribution. First, the local government has to build a mechanism to promote poor people's participation in rural tourism, to fully consider the ability of the underprivileged population, to participate in their aspirations and opportunities, and to get the poor as much as possible to participate in the development of rural tourism, including the choice, development, and management of the program. In addition, allowing the poor to participate in the rural tourism business through funds, land, and human resources to get a stake in the country, and to help those who have been actively out of poverty, to participate in the development of rural tourism, and to actually benefit from it. And secondly, there's a way to train people in the area, in particular, to increase the training of the poor, to increase their ability to learn and to develop their own. Through skill training, the participation consciousness of poor villagers can be raised, their self-confidence will be enhanced, and their ideas will be changed so that the poor population can actively integrate into the business activities in the introduction of tourism investment enterprises.

\section{CONCLUSION}

The development of tourism can be very useful in the development of the economy of the poor region. Tourism poverty is an important way to get rich out of poverty in this country, and it's a typical form of "hematopoi-type" poverty alleviation, and the poor population has a lot of people, and the poverty rate is low, and the poverty alleviation is good. The tourism industry chain can drive the development of many related industries in the region, which has a huge driving effect on the economic development of the poverty-stricken areas. In order to better promote tourism poverty alleviation and development, we should actively extend the industrial chain, strengthen the integration of industrial chain, accelerate the localization of the industrial chain of tourism poverty alleviation, accelerate the development of the core enterprises of tourism poverty alleviation, build a multi-channel financing system, participate in the multi subject, improve the system of benefit distribution and enhance the awareness of the participation of the poor people.

\section{REFERENCES}

[1] Zhang Dong, Ni Xiangli. From the perspective of industrial chain, poverty alleviation in the poverty-stricken minority areas: a case study of Huize County in Yunnan province [J]. Contemporary economy, 2018 (01): 58-61

[2] Lv Linxin. The optimization of Shanxi rural tourism industry chain under the background of poverty alleviation [D]. Shanxi University of Finance and Economics, 2017.

[3] Deng Weijie, He Haiyan, Zhu Shuting. The predicament and Countermeasures of precision poverty alleviation in rural tourism [J]. Rural economy, 2017 (12): 44-49.

[4] Wang Hui. Study on the development mode of rural tourism under the background of tourism poverty alleviation [J]. China Agricultural Resources and zoning, 2017, 38 (03): 198-201

[5] Zhang Chunmei, Huang Hongdi, Zeng. Rural tourism precision poverty alleviation operation mechanism, realistic predicament and solution path [J]. Journal of agriculture and forestry economic management, 2016, 15 (06): 625-631.

[6] Mao Feng. Rural tourism poverty alleviation model innovation and strategy deepening [J]. Chinese agricultural resources and zoning, 2016, 37 (10): 212-217

[7] Jiang Huanzhou. Practice of tourism poverty alleviation in ethnic minority areas of Guizhou: effects, problems and Countermeasures [J]. Journal of Guangxi University of Finance and Economics, 2014, 27 (01): 34-37+48.

[8] Deng Xiaohai, Zeng Liang, Luo Mingyi. Diagnosis and Countermeasures of tourism Poverty Alleviation under the perspective of industrial chain $[\mathrm{J}]$. Contemporary economic management, 2014, 36 (11): 56-59. 